\title{
Practical Teaching Reform Research on Logistics Management from "Industry-University-Research" Perspective
}

\author{
Yunqiu Jiao* \\ Economy and Management Department \\ Weifang University \\ Weifang, China \\ wfjyqd@163.com
}

\begin{abstract}
With the rapid development of China's logistics industry, the lack of logistics professionals, especially the highquality and complex logistics personnel, has become one of the bottlenecks restricting the healthy development of logistics industry. This thesis aimed to analyze developing strategies for the local undergraduate institution focusing on cultivating applied talents, by combining the specific needs of professionals in the modern logistics industry, actively exploring new ways of "Industry-University-Research" and further deepening practical teaching reform, it put forward recommendations on cultivating composite logistics talents with high-quality and disciplinecharacteristic.
\end{abstract}

Keywords-Industry-University collaboration; Logistics management; Applied talents; Practical teaching system

\section{INTRODUCTION}

With the rapid development of China's logistics industry, the importance of training logistics professionals has become increasingly prominent. In recent years, although many colleges and universities have set up logistics management majors, these graduates have failed to fill in the gaps in professional logistics talents, especially the smart logistics talents who understand the logistics business and are familiar with advanced technologies such as the Internet of Things and cloud computing. Very large, the employer's "recruitment difficult"and college graduates "difficulty in employment" still exists. The main reason for this kind of supply and demand upside down is that the logistics talents cultivated by colleges and universities have the problems of weaker hands-on capabilities and insufficient innovation capacity. Practical teaching is an important part of the logistics management professional curriculum system, and it is an important way to cultivate human resources. As a local undergraduate university that focuses on training application-oriented logistics personnel, we should focus on practical teaching reform, and actively explore new ways of "Industry-University-Research" to educate people. We must fully consider the discipline characteristics of logistics management and combine the actual employment needs of corporate positions. Construct a scientific and reasonable practical curriculum system, and strive to cultivate high-quality composite logistics personnel.

\section{PROBLEMS IN PRACTICAL TEACHING OF LOGISTICS MANAGEMENT SPECIALTY}

\section{A. Homogenization of Training Objectives, Non-Accurate Professional Positioning}

Due to the short duration of schooling and other reasons, most colleges and universities lack the systematic research and overall design when formulating the training objectives of the logistics management profession, and are not sufficiently deep in integration with the needs of regional economic and social development. Therefore, the homogenization problem prevails in the training objectives. It does not reflect the characteristics, professional positioning is not accurate enough, and the logistics industry is currently far from the actual needs of high-quality composite logistics personnel, thus affecting the quality of personnel training.

\section{B. Unreasonable Curriculum System Setup}

First of all, many colleges and universities in the curriculum system, practice courses and theoretical courses are often set up independently, practice classes are relatively few, and emphasis on the basic practice, most of the business visits, bar code generation demonstration and other cognitive practice and confirmatory practice, Lack of comprehensive training in logistics design, logistics system development, etc. [3]; Second, ignoring cross-professional linkage, lack of crossprofessional courses and innovation and entrepreneurship curriculum. With the advent of smart logistics, the linkage development of cross-border integration of the logistics industry and other industries has become an inevitable trend. However, colleges and universities have not been able to adjust the training program in time. There are very few intermediate professional courses in the curriculum, and there is no innovation consciousness and innovation ability. The training objectives are integrated into the curriculum setting [1]. Unreasonable curriculum setting leads to obvious lack of students' practical ability and innovation ability. After employment, it is often difficult to adapt to work in the short term. Most of them need the company to conduct systematic professional training before they can take up posts. 


\section{Teaching Methods and Teaching Contents Lack Meticulous Design}

With the continuous deepening of teaching reforms, although some of them use project teaching methods and roleplaying methods, most of them are still taught by teachers. In practice teaching, it is usually based on the teacher explaining the presentation and the grouping cycle operation of the student. The content of the training is given by the teacher in advance, and the operation can be performed according to the steps. The hands-on operation is relatively mechanically simple. In addition, some teachers tend to focus on the laboratory's related software and experimental instructions when they direct experimental training. This type of teaching method can hardly inspire students' interest in learning. Some teachers use the textbooks as their basis and lack the textbooks. The in-depth processing of the content, the lack of careful design of the organization and guidance of student activities, is not conducive to inspiring students' imagination and innovative thinking [1].

\section{Single form of Practical Teaching}

At present, there are two main forms of practical teaching in logistics: simulation training in schools and off-campus practice teaching. In the practical training in schools, many local colleges and universities have problems such as insufficient funds, limited venues, shortage or outdated equipment, slow software updates, and shortage of professional teachers. Practical training conditions cannot meet the requirements of practical teaching; because the school and the company did not form an effective mechanism for joint training of professional talents and did not have substantive cooperation projects, companies often refused to accept students' internships due to various considerations such as trade secrets, operational safety, and production rhythm. Inconsistent with the phenomenon of non-cooperation, most of the off-campus internships stay on the level of company visits, simple labor, etc. The actual teaching results are poor.

\section{E. Lack of Experienced and High-level Practical Instructors}

As an emerging profession, most of the teachers of logistics management are transferred from economic management or other majors. They lack systematic research on modern logistics and are not familiar with logistics practice teaching. The newly-introduced Ph.D. in logistics management is a graduate. After teaching directly to colleges and universities, there is no industry experience and lack of practical experience. Therefore, colleges and uni versities urgently need to establish a high-level practical teaching faculty with practical experience.

\section{PRACTICE TEACHING REFORM MODE}

\section{A. Define Personnel Training Goal, Improve Practical Teaching Curriculum System}

Application-oriented colleges and universities should deeply understand the same professional training programs at different levels of colleges and universities, closely integrate the development trend of the logistics industry and regional economic and social development direction, rational allocation and optimization of teaching resources, give full play to its own discipline construction and talent cultivation advantages Clarifies the cultivation of innovative and applied high-quality talents and formulates distinctive personnel training programs.

The curriculum system should be set scientifically and reasonably on the basis of full consideration of the academic superiority of colleges and universities and the employment needs of enterprises. First of all, we should improve the ratio of practical teaching hours and practice teaching throughout the entire professional teaching. Encourage the addition of experimental hours and the establishment of separate experimental training courses in professional theoretical courses. Second, in the face of new business models and the need for smart logistics, the past purely academic system should be changed, students should be encouraged to choose cross-curricular elective courses, and be perfect and crossprofessional. Cultivate the combination of innovative entrepreneurship education curriculum system, broaden the students' knowledge face, and strive to enhance students' comprehensive innovation ability and practical ability to meet the professional requirements of the company for students. In view of this, we should actively promote the deep integration of "production, study, and research" and build a multi-level and progressive "production, study, and research" education system under the perspective of collaborative education [1] [5]. As shown in Fig. 1

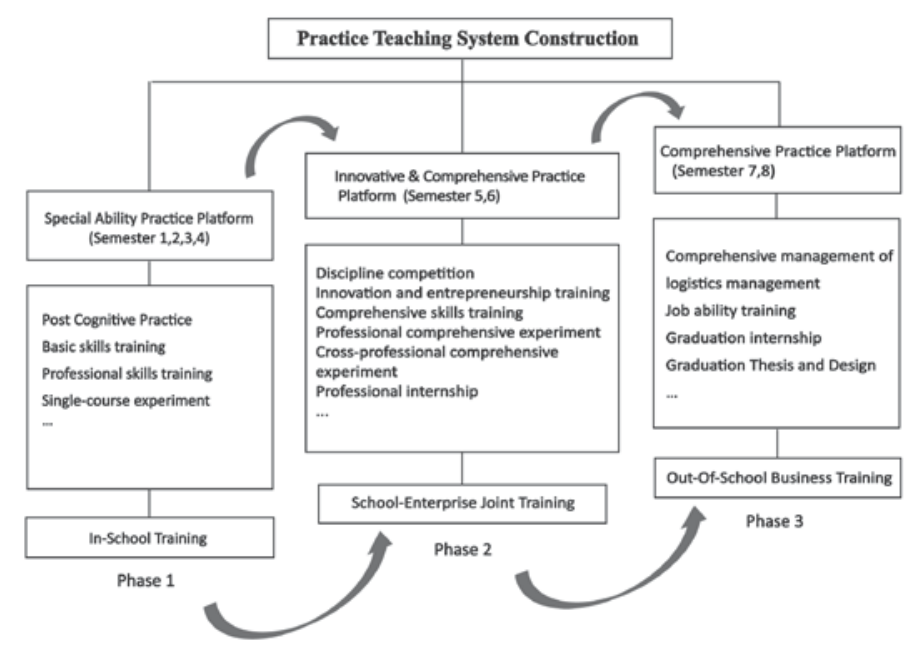

Fig. 1. Education System under Perspective of Collaborative Education

\section{B. Innovating Teaching Mode, Optimizing Practical Teaching Contents}

Encourage teachers to use teaching models such as heuristics, role-playing, project teaching, and cooperative learning that are more flexible and conducive to student learning. In practice teaching, students' main role and teacher's guiding role are emphasized, and scientific inquiry is used as the main method to acquire knowledge, inspiring students' interest in learning and subjective initiative.

Exploring and experimenting with the contextualized digital teaching model, in which teachers use interactive smartphones and PADs to teach and wirelessly interconnect to effectively integrate the "teaching" "learning" and "assessment" links to achieve interactive teaching, real-time 
assessment, and teaching resource sharing. And other features. Colleges and universities should support students to carry out mobile, personalized and inquiry-based hybrid learning, with the theme of "intelligent logistics", to achieve seamless integration of classroom and laboratory simulation and teaching systems such as storage and transportation. In the simulation practice environment, teachers and students are interconnected in real time and timely feedback of practical results, to achieve the integration of theory and practice, teaching and evaluation of intelligent teaching [6].

Promote the teaching model of "combination of competition with education, study with competition" to improve students' innovative ability. Relying on the "allopening” type laboratory, set up a discipline competition platform and organize students to participate in various discipline competitions such as the National College Student Logistics Design Competition and the National Supply Chain Operation Manage "combination of sports and teaching with learning and competition" to cultivate college students' teamwork spirit and practical innovation ability. In the teaching process, the content of practical teaching is adjusted according to the competition project, and the corresponding teaching tasks are designed based on project-oriented teaching. The task decomposition of the competition is designed into different ability assessment projects and integrated into the teaching content, ensuring that students can participate even if they do not participate in the competition. Proficient in the relevant logistics operation skills, both to meet the requirements of the competition, but also qualified for the actual logistics job requirements. In this way, students will be able to seamlessly connect to the enterprise in the future, and they will be able to perform their posts quickly by doing training [4].

\section{Developing Innovative Experimental Projects and Strengthening Practical Bases Construction}

First of all, in practical teaching in schools, colleges and universities should fully consider the students' concerns and interests, optimize comprehensive, design, and innovative experimental projects, so that students can perform comprehensive logistics skills training in the simulation practice to improve Students' practical ability in logistics and their ability to innovate; Second, in the off-campus practice teaching, they should select various types of businesses with different business characteristics, jointly build an off-campus practice base, and promote the "production, study and research" cooperative education program to strengthen multiparty cooperation. Realize resource integration [1]. We should strive to change the existing single-surface cooperation model based on visits, and carry out multi-faceted and in-depth cooperation with enterprises in a planned, hierarchical and allround manner. In addition, we can also actively explore new models such as "campus logistics supermarkets", that is, schools provide venues, enterprises deploy related facilities and equipment, parcels are collected, entered, sorted, tracked, issued, etc. The company only needs to guide, monitor and manage the entire business process and provide certain labor remuneration. In this way, through the establishment of a real logistics business platform, students' practical skills can be better improved [3].

\section{Creating an Excellent Practical Teaching Team}

Colleges and universities should take effective measures to increase foreign reference and internal training, and establish a "double-qualified" faculty with strong theoretical and practical abilities and reasonable personnel hierarchy. You can cultivate dual-qualifications with both theoretical and practical abilities by encouraging professional teachers to pursue crossprofessional training, domestic and international visits, job training, academic competitions, degree studies, qualification certificates for professional competency, and participation in seminars and exchanges. At the same time, the company can employ engineering and technical personnel with years of work experience and higher education to serve as part-time teachers. Through the establishment of professional courses, the seminars on logistics topics are held to guide students in the curriculum design, subject competition, production internship, graduation design, etc., and participate in logistics practical teaching to improve the effectiveness of practical teaching.

\section{E. Constructing Scientific Quality Evaluation and Monitoring System for Practical Teaching}

Practice teaching itself is a part of curriculum teaching. To achieve results in practical teaching, an effective practical teaching evaluation and monitoring system must be established. First, a scientific and rational pre-assessment mechanism should be established to comprehensively evaluate the teaching plan, form, content, faculty resources, and resource platform of practical teaching; secondly, attention should be paid to monitoring during events, and the quality of practical teaching should be included in the regular teaching of the school. During the inspection, the practice teaching should be avoided in the form; finally, the post-constructive comprehensive evaluation of the quality of practical teaching should be carried out, and the students' practical ability should be strictly assessed and evaluated [2]. In the specific assessment, the school and the company can jointly form the evaluation and supervision main body. On the one hand, it is responsible for integrating the specific performance of the students in the process of completing the practical training internship project, from the multidimensional dimension of professional ethics, technical skills, innovation ability and so on.

\section{SAFEGUARD MEASURES FOR EFFECTIVE} IMPLEMENTATION OF PRACTICAL TEACHING REFORM

\section{A. Safeguard Measures from Social Level}

The government should give full play to its advantages in policy regulation and optimization of resource allocation, and by promulgating and improving relevant policies and regulations, it will provide a strong legal and policy basis for the smooth development of "producing, research, and researching" cooperative education, and ensure that both schools and enterprises can share Benefits: The optimization and reorganization of educational resources and market resources will enable school-enterprise cooperation to become a benefit for businesses, schools, and the nation.

Industry associations should take the initiative to create a bridge for school-enterprise cooperation, and jointly establish 
"intelligent logistics education talents cultivation base" with many universities and enterprises. In accordance with the principle of "resource sharing, complementary advantages, sharing of responsibilities, and benefit-sharing", we have built a courier operations training room, a transport scheduling training room, a simulation planning training room, a $\mathrm{B} 2 \mathrm{C}$ ecommerce logistics center training room, and intelligent technical equipment. Schools and enterprises jointly formulate a training room construction plan that integrates new models, new technologies, and new equipment, and strive to keep the training environment and the industry's technological development levels in synch with or ahead of others. In addition to being used for professional practice teaching, the completed training base can also be used as a corporate employee training, vocational skill appraisal, technical service, etc., and give full play to the "production, learning and research" effect [7].

\section{B. Safeguard Measures from School Level}

Schools should attach great importance to the practical teaching of logistics management, and fully support professional construction from the aspects of policies and systems, faculty and funding sites. First of all, it is necessary to ensure the proportion of practical teaching from the institutional perspective, encourage teachers to participate in the reform of practical teaching, and encourage teachers to go to work for enterprises and guide discipline competitions so as to improve the level of practical teaching as soon as possible. Secondly, we must ensure the construction of logistics professional campus laboratories and practical training bases from capital and venues, and build innovation and entrepreneurship platforms to ensure the smooth development of innovative experimental activities such as experimental training and academic competitions; in addition, universities should integrate their own Resources and advantages, and actively provide services for enterprises, such as technology research and development and application, enterprise development strategy consulting, staff training, graduates, etc., so that companies from passive cooperation into active participation, so as to ensure the quality of practice teaching.

\section{Safeguard Measures from Corporate Level}

Enterprises should actively explore co-construction of laboratories or practical bases with universities; actively participate in the various aspects of personnel training in colleges and universities, such as the development of talent training programs, experimental course development, selection of professional textbooks, professional education for admission, curriculum training, academic competitions, and majors Internships, graduation sessions, employment and postemployment information feedback and other activities; actively provide opportunities for student internships, and send excellent instructors to guide students to promote a thorough understanding of corporate culture, operating procedures and business philosophy, and lay a foundation for attracting outstanding talents in the future; Exchanges and cooperation with university experts and scholars, and strive to achieve organizational innovation, process reengineering, equipment upgrades, etc., and then improve the operating efficiency of the company to obtain new profit growth point [3].

\section{CONCLUSIONS}

Logistics management major is a cross-disciplinary subject with strong application. Practical teaching is an important part of its professional training program, and it is also an important part in cultivating students' practical ability, innovation ability and comprehensive quality. Local universities for applied applications should aim at the problems existing in practical teaching, from improving course systems, innovating teaching models, developing the innovative experimental projects, strengthening practice base construction, building excellent teaching teams, and building scientific practical teaching. The quality evaluation and monitoring system, etc., further deepen the reform of practical teaching; the deep integration of "production, study and research" should be actively promoted, and the principle of "mutual benefit through cooperation, mutual complementary" should be adopted between the school and enterprise. Training and practice, employment and other aspects of the sharing of multilateral cooperation mechanisms to jointly develop the qualified logistics personnel in line with the needs of high-quality composite logistics personnel.

\section{ACKNOWLEDGMENT}

This research was financially supported by Ministry of Education Industry-University Cooperation Collaborative Education Project (Project No. 201602028046), Ministry of Education Industry-University Cooperation Collaborative Education Project (Project No. 201702067027), Ministry of Education Collaborative Education Project (Project No. 201702068055), Shandong Province Human \& Social Science Program (Project No.17-ND-JJ-15), hereby expresses thanks to them.

\section{REFERENCES}

[1] Feng Zhang, Xuelong Zhang, "Exploration and Practice of Logistics Management Practice Teaching System Based on Cultivation of Innovation and Entrepreneurship”, Transportation Enterprise Management, vol.6, pp.129-131, April 2017(In Chinese).

[2] Xia Yu, "Research on the Construction and Guarantee of Practical Teaching System of Logistics Management in Undergraduate Colleges”, China Market, vol.37, pp.94-95, July 2017(In Chinese).

[3] Yongfei Han, "Research on the Practical Teaching Reform of Logistics Management Based on Talents Cultivation”, Journal of Inner Mongolia Agricultural University(Social Science Edition), vol.4, pp.84-87, August 2017(In Chinese)

[4] Jingdan Wu, "Research and Application of "Integrated Learning Competition" Teaching Based on Modern Logistics Skills Competition”, New Campus, vol.6, pp.30-31, March 2017(In Chinese).

[5] Hongmei Gao, Hao Zhang, Junde Han, “Construction of Core Practical Ability System of Application-oriented Undergraduate Logistics Management: A Case Study of Tianjin Agricultural College”, Logistics Technology, vol.10, pp.175-179, September 2017(In Chinese).

[6] Yinghui Wu, "Study ideas for the construction of talents training program for university logistics under the environment of smart logistics”, Journal of Higher Education, vol.5, pp.161-162, March 2017(In Chinese)

[7] Fang Qin, "Practical Teaching of Logistics Management Based on Innovation Practice”, Logistics Sci-Tech, vol.1, pp.156-157, January 2018(In Chinese). 